\title{
DISTRIBUSI PENDAPATAN PETANI KARET DI DESA SEI. TONANG KECAMATAN KAMPAR UTARA KABUPATEN KAMPAR
}

\author{
Eliza, Shorea Khaswarina dan Melysari Nasution \\ Staf Pengajar Jurusan Agribisnis Faperta Universitas Riau (UR) \\ Alumni Jurusan Agribisnis Faperta Universitas Riau (UR)
}

\begin{abstract}
ABSTRAK
Tujuan penelitian ini adalah untuk mengetahui distribusi pendapatan rumah tangga dan ketimpangan pendapatan rumah tangga petani karet di Desa Sei. Tonang Kecamatan Kampar Utara Kabupaten Kampar. Penelitian ini dilaksanakan dari bulan Desember 2012 sampai dengan Juni 2013. Metode penelitian yang digunakan adalah metode survei. Pengambilan sampel dilakukan dengan purposive sampling terhadap 38 petani karet yang luas lahan 1-6 hektar dengan umur tanaman 20-25 tahun.Hasil Penelitian menunujukkan bahwa pendapatan petani karet di Desa Sei. Tonang dengan pendapatan diantara Rp. 2.095.913 - Rp. 15.429.336. Dengan rata-rata pendapatan Rp.6.042.585. yang terdiri dari pendapatan sektor pertanian $97,26 \%$ dan di luar sektor pertanian 2,74\%. Angka Indeks Gini Rasio sebesar 0,20 menunjukkan distribusi pendapatan rumah tangga petani karet sudah cukup merata dengan tingkat ketimpangan pendapatan rendah dan Kurva Lorenz mendekati garis kemerataan sempurna
\end{abstract}

Kata Kunci: Karet, Distribusi pendapatan,Ketimpangan pendapatan

\section{PENDAHULUAN}

Pembangunan pertanian khususnya di subsektor perkebunan di daerah Provinsi Riau memiliki andil yang cukup besar untuk merealisasikan tujuan tersebut. Salah satu diantara beberapa komoditi perkebunan yang potensial dikembangkan dalam rangka meningkatkan kesejahteraan petani pedesaan di Provinsi Riau adalah karet yang sudah membudidaya dalam kehidupan masyarakat sehari-hari sejak tahun 1967 hingga sekarang (Irawan dan Sadikin, 2004).

Perkebunan karet merupakan salah satu komoditi primadona perkebunan di Kabupaten Kampar yang sudah membudaya dalam kehidupan masyarakat. Pada tahun 2011 Persentase perkebunan karet di Kabupaten Kampar tercatat 91.720 Ha luas lahan dan didalamnya kecamatan Kampar Utara seluas 3.902 Ha dengan jumlah petani 2.815 orang dan produksi pada tahun 2011 adalah 2.633 ton (Dinas Perkebunan Kabupaten Kampar, 2012).

Desa Sei.Tonang merupakan salah satu desa dengan penduduk umumnya bergerak dibidang pertanian, seperti usahatani padi dan karet. Usahatani karet merupakan mata pencaharian pokok di desa Sei. Tonang selain usahatani padi dan pedagang. Namun produksi yang sedikit dan harga produk yang rendah sehingga pendapatan akan menurun, produksi yang sedikit ini dikarenakan banyaknya petani dengan modal terbatas (Sugiarto, 2008). Kendala diatas perlu dikaji lebih mendalam agar diperoleh gambaran yang menyeluruh tentang distribusi pendapatan di Desa Sei. Tonang Kecamatan Kampar Utara Kabupaten Kampar.

Tujuan penelitian adalah menganalisis distribusi pendapatan dan ketimpangangan pendapatan rumah tangga petani karet di Desa Sei. Tonang Kecamatan Kampar Utara. 


\section{METODOLOGI PENELITIAN}

Penelitian dilakukan di Desa Sei. Tonang Kecamatan Kampar Utara Kabupaten Kampar yang merupakan suatu desa di Kecamatan Kampar sebagai daerah pengembangan pertanian khususnya perkebunan karet. Objek penelitian adalah rumah tangga petani karet Desa Sei. Tonang. Metode penelitian adalah metode survey yaitu metode melalui wawancara dan pengisian kuisioner oleh responden terpilih. Populasi penelitian rumah tangga petani karet desa Sei. Tonang dengan jumlah keseluruhan petani karet adalah 150 termasuk didalamnya $50 \%$ petani dengan tanaman karet berumur 20 - 25 tahun. Sampel diambil sebanyak $50 \%$ dari jumlah kepala keluarga $(\mathrm{KK})$ petani karet yang berumur $20-25$ yaitu 38 petani karet yang bermukim di Desa Sei. Tonang. Pengambilan sampel dilakukan dengan cara Purposive Sampling (sengaja) dengan pertimbangan petani karet yang tanamannya berumur 20-25 tahun dan luas lahan 1 - 6 ha (diasumsikan produksinya hampir sama).

Analisis data dilakukan sesuai dengan tujuan penelitian. Data yang diperoleh akan ditabulasikan dan kemudian dianalisis dengan berbagai perhitungan diantaranya distribusi pendapatan dengan menggunakan Indeks Gini (Gini Index Ratio) Secara umum penghitungan Indeks Gini (H.T Oshima dalam Widodo, 1990).dirumuskan sebagai berikut:

$$
\begin{aligned}
& \mathrm{GC}=1-\sum_{1}^{n}\left(\mathbf{X}_{\mathrm{i}-1}-\mathbf{X}_{\mathrm{i}}\right)\left(\mathbf{Y}_{\mathrm{i}}+\mathbf{Y}_{\mathrm{i}-1}\right) \\
& \mathbf{G C}=\mathbf{1}-\sum_{1^{*}}^{n} f_{\mathrm{i}}\left(\mathbf{Y}_{\mathrm{i}}+\mathbf{Y}_{\mathrm{i}-1}\right)
\end{aligned}
$$

Dimana:

\section{$\mathrm{GC}=$ Angka Gini Coefficient}

$\mathrm{X}_{\mathrm{i}}=$ Proporsi jumlah rumah tangga kumulatif dalam kelas i

fi $=$ Proporsi jumlah rumah tangga dalam kelas i

$\mathrm{Y}_{\mathrm{i}} \quad=$ Proporsi jumlah pendapatan rumah tangga kumulatif dalam kelas- $\mathrm{i}$
Menurut Shorrock dalam Wulan 2011, pengukuran ketimpangan pendapatan dengan menggunakan alat pengukur ketimpangan Koefisien Gini dan Koefisien Variasi merupakan alat ukur yang paling baik, karena komponen penyusun Koefisien Gini dapat digunakan untuk melihat berbagai komponen yang menjadi penyebab ketimpangan yang terjadi berdasarkan komponen pendapatan dan sumber - sumber pendapatan. Kriteria Indeks Gini menurut Todaro (1990) menetapkan kriteria:

1. Bila angka Gini Ratio berada pada nilai $<0,4$ berarti distribusi pendapatan berada pada ketimpangan rendah.

2. Bila angka Gini Ratio berada pada nilai $0,4-0,5$ berarti distribusi pendapatan berada pada ketimpangan sedang.

3. Bila angka Gini Ratio berada pada nilai $>0,5$ berarti tingkat ketimpangan distribusi yang tinggi.

Distribusi pendapatan dapat juga diterangkan dengan menggunakan Kurva Lorenz. Kurva Lorenz akan memperlihatkan hubungan kuantitatif antara persentase penerima pendapatan dan persentase total pendapatan yang diperoleh. Semakin jauh jarak Kurva Lorenz dari garis diagonal (yang merupakan garis pemerataan sempurna), maka semakin timpang atau tidak merata distribusi pendapatannya.

\section{HASIL DAN PEMBAHASAN Deskripsi Umum Daerah Penelitian}

Lokasi penelitian dilaksanakan di Desa Sei. Tonang yang merupakan salah satu desa di Kecamatan Kampar Utara. Desa Sei. Tonang memiliki luas wilayah yaitu 1.025 Ha termasuk penggunaan lahan perkebunan karet seluas 152 ha sebagai lahan aktivitas sumber mata pencaharian masyarakat dengan penduduk sebanyak 400 Kepala Keluarga (KK) ( BPS Kampar, 2011). Secara geografis keadaan Desa Sei. Tonang sebagai berikut 
Sebelah Utara berbatasan dengan Desa Bukit Sembilan, Sebelah Selatan berbatasan dengan Sungai Kampar, Sebelah Barat berbatasan dengan Desa Pulau Lawas, Sebelah Timur berbatasan dengan Desa Muara Jalai.

Keadaan alam, iklim dan struktur tanah sangat menentukan keberhasilan produksi pertanian. Desa Sei. Tonang memiliki permukaan dataran rendah dengan ketinggian tempat kurang lebih 60 meter dari permukaan laut, dengan suhu udara $250 \mathrm{C}-31$ oC dan merupakan daerah beriklim tropis (BPS Kampar, 2010). Faktor-faktor tersebut dijadikan pedoman dalam menentukan tipe usahatani. Usaha perkebunan karet menjadi usaha yang sangat sesuai dan menguntungkan di Desa Sei. Tonang dikarenakan keadaan alam, iklim dan struktur yang sesuai untuk komoditi tersebut.

\section{Identitas Petani Sampel}

Petani sebagai pekerja dan pengelola memegang peran penting dalam usahatani yang dituntut untuk mengoptimalkan sumberdaya terbatas dan melalui pengalokasian secara efesien sehingga akan mempengaruhi pendapatan yang diperoleh, Keberhasilan usahatani yang dilakukan petani ditentukan oleh identitas atau potensi petani seperti faktor fisik dan faktor sosial ekonomi. Faktor tersebut dapat dilihat dari umur, tingkat pendidikan, jumlah tanggungan keluarga, luas lahan dan pengalaman berusahatani.

\section{Umur Petani Sampel}

Umur merupakan faktor internal yang mempengaruhi kinerja atau kemampuan petani dalam menjalankan aktivitas usahatani. Seseorang yang memiliki umur lebih muda memiliki kemampuan fisik yang lebih kuat dalam mengelola usahatani serta mudah dalam mengadopsi inovasi baru bila dibandingkan dengan orang yang memiliki umur lebih tua. Hal tersebut dapat berpengaruh terhadap kuantitas produksi yang dihasilkan. Pembagian petani berdasarkan kelompok umur dapat dilihat pada Tabel 1.

Tabel 1. Tingkat Umur Petani Karet di Desa Sei. Tonang

\begin{tabular}{cccc}
\hline No. & Uraian & Jumlah Sampel (Jiwa) & Persentase (\%) \\
\hline 1 & Kelompok Umur (Tahun) & 6 & 15.79 \\
& a. $21-30$ & 6 & 15.79 \\
b. $31-40$ & 10 & 26.32 \\
c. $41-50$ & 10 & 26.32 \\
d. $51-60$ & 6 & 15.79 \\
e. $>60$ & 38 & 100 \\
\hline
\end{tabular}

Sumber Data: Data olahan, 2013

Menurut Soekirno (1994), usia produktif berkisar antara umur 15 - 54 tahun. Hasil survei di lapangan menunjukan bahwa usia petani karet rata-rata berkisar antara 47 tahun. Jika dilihat dari rata - rata usia tersebut dapat digolongkan bahwa petani karet di Desa Sei. Tonang termasuk pada usia produktif, sehingga dapat memberikan indikasi yaitu para petani tersebut masih memiliki kemampuan dan potensi baik fisik maupun mental untuk bekerja dengan baik, sehingga bisa menghasilkan pendapatan yang memadai dan mempunyai tanggung jawab sosial terhadap penghidupan seluruh anggota keluarganya.

\section{Tingkat Pendidikan}

Pendidikan berfungsi menyiapkan salah satu input dalam proses produksi, yaitu tenaga kerja agar dapat bekerja dengan produktif, dengan begitu diharapkan dapat 
mengatasi keterbelakangan ekonomi dengan meningkatkan kemampuan manusia dan motivasi manusia untuk berprestasi. Dalam penelitian ini pendidikan petani yang diamati adalah tingkat pendidikan formal yang diuraikan dari tingkat pendidikan terendah sampai yang tertinggi. Pembagian petani berdasarkan tingkat pendidikan dapat dilihat pada tabel 2.

Tabel 2. Tingkat Pendidikan Petani Karet di Desa Sei. Tonang.

\begin{tabular}{lccc}
\hline & Tingkat Pendidikan & Jumlah (Jiwa) & Persentase (\%) \\
\hline a. SD & 11 & 28.95 \\
b. SLTP & 18 & 47.37 \\
c. SMA & 9 & 23.68 \\
\hline Jumlah & 38 & 100 \\
\hline
\end{tabular}

Sumber Data: Data Olahan, 2013

Tabel 2 menunjukkan bahwa sebagian besar petani berada dalam tingkat pendidikan jenjang SLTP dan SD, yaitu sebanyak $47,37 \%$ dan $28,95 \%$. Namun disamping itu, sebagian petani berada pada tingkat SMA sebanyak $23,68 \%$. Petani dalam penelitian ini dapat digolongkan bahwa tingkat pendidikan petani masih rendah. Rendahnya pendidikan petani karet tersebut dapat dibantu dengan diberikannya penyuluhan atau pelatihan yang dilaksanakan oleh pemerintah maupun swasta seperti penyuluhan dari Dinas Pertanian. Penyuluhan dan pelatihan yang dilakukan diharapkan dapat membantu petani dalam meningkatkan usaha pertaniannya dalam konteks penerapan teknologi yang lebih maju dan efisien. Dengan demikian, diharapkan juga dapat meningkatkan pendapatan petani karet.

\section{Pengalaman Usaha Tani}

Pengalaman berusahatani memegang peranan penting dalam proses usahatani.
Dengan bertambahnya pengalaman berusahatani, maka pengetahuan dan keterampilan para petani akan terus meningkat. Hal ini disebabkan karena para petani sudah tahu cara atau metode bagaimana menghadapi musim tanam dan fluktuasi harga yang berubah-ubah sehingga pada akhirnya dapat meningkatkan pendapatan mereka.

Tabel 3 menunjukkan bahwa pengalaman berusahatani petani cukup lama yaitu rata rata 18 tahun. Petani dengan pengalaman usaha 11-15 tahun dengan persentase $21,05 \%$, sedangkan petani dengan pengalaman usaha 6-10 tahun dan diatas 20 tahun yaitu sama dengan persentase $31,58 \%$. Petani paling sedikit dengan pengalaman usahatani 16-20 tahun yaitu sebanyak $15,79 \%$. Hasil pengalaman usahatani petani sampel di Desa Sei. Tonang dapat dilihat pada Tabel 3.

Tabel 3. Tingkat Pengalaman Berusahatani Petani Karet di Desa Sei. Tonang.

\begin{tabular}{cccc}
\hline No. & Pengalaman Berusahatani (Tahun) & Jumlah Sampel (Jiwa) & Persentase (\%) \\
\hline 1 & $6-10$ & 12 & 31.58 \\
2 & $11-15$ & 8 & 21.05 \\
3 & $16-20$ & 6 & 15.79 \\
4 & $>20$ & 12 & 31.58 \\
& Jumlah & 38 & 100 \\
& Rata-rata & 18 & \\
\hline
\end{tabular}

Sumber Data: Data Olahan, 2013. 
Tabel 2 menggambarkan bahwa petani karet yang menjadi sampel pada penelitian ini seharusnya telah memiliki keterampilan yang baik dalam menjalankan usahataninya terutama dalam mengalokasikan faktor produksi dan penerapan tekhnologi yang semakin baik agar dapat meningkatkan pendapatan yang mereka peroleh.

\section{Luas Lahan Pertanian}

Tanah sebagai harta produktif adalah bagian organis rumah tangga petani. Luas lahan usahatani menentukan pendapatan, taraf hidup, dan derajat kesejahteraan rumah tangga petani, juga akan mempengaruhi skala usaha yang dimiliki petani. Semakin luas lahan yang dimiliki maka berbanding lurus terhadap pendapatan sehingga kemungkinan penambahan pendapatan akan semakin besar, karena luas lahan sangat menentukan hasil dan produksi usahatani karet.

Fadholi (1988) dalam Putra (2007) menjelaskan, pada dasarnya dapat dijelaskan 4 golongan petani berdasarkan tanahnya, yaitu: (1). Golongan petani luas (>2 Ha), (2) Golongan petani sedang $(0,5-2 \mathrm{Ha})$, (3) Golongan petani sempit (0,5 $\mathrm{Ha}), \quad$ (4) Golongan buruh tani

Tabel 4 menunjukkan sebagian besar petani sampel memiliki luas lahan sebanyak 2 Ha. Artinya, dalam teori Fadholi petani sampel dalam penelitian merupakan golongan petani sedang ( $0,5-2 \mathrm{Ha}$ ) yang merupakan lahan sendiri dari warisan dan lahan hutan yang dibuka sendiri oleh warga, namun sebagian petani sebanyak 8 ( $22 \%$ ) jiwa tergolong kepada petani luas ( $>2 \mathrm{Ha}$ ) yang memiliki luas lahan lebih dari $2 \mathrm{Ha}$. Hal tersebut dikarenakan sebagian pendapatannya hasil dari merantau ke negeri jiran Malaysia di belanjakan untuk membeli lahan dari petani lain yang menjualnya. Luas lahan yang dimiliki petani sampel dapat dilihat pada Tabel 4.

Tabel 4. Tingkat Luas Lahan Petani Karet di Desa Sei. Tonang.

\begin{tabular}{ccc}
\hline Luas Lahan (Hektar) & Jumlah (Jiwa) & Persen (\%) \\
\hline a. $0-0,5$ & 0 & 0 \\
b. $0,5-2$ & 30 & 78 \\
c. $>2$ & 8 & 22 \\
Jumlah & 38 & 100 \\
\hline Rata-rata & 2 &
\end{tabular}

Sumber Data: Data Olahan, 2013

\section{Jumlah Tanggungan Keluarga}

Jumlah tanggungan keluarga adalah jumlah seluruh anggota keluarga yang sekolah dan yang belum bekerja serta masih berada dalam tanggungan yang bekerja dalam keluarga tersebut. Jumlah tanggungan akan berpengaruh terhadap pendapatan dan pengeluaran keluarga untuk memenuhi kebutuhan hidup anggota keluarga. Besarnya pendapatan dan pengeluaran akan mempengaruhi terhadap kesejahteraan petani sampel. Semakin besar tanggungan keluarga maka semakin besar pula tanggungan yang dipikul kepala keluarga dalam memenuhi kebutuhan hidup keluarganya. Pada Tabel 5 dapat dilihat jumlah petani sampel karet berdasarkan jumlah tanggungan kepala keluarganya.

Tabel 5. Jumlah Tanggungan Keluarga Petani Karet di Desa Sei. Tonang.

\begin{tabular}{cccc}
\hline No & Jumlah Tanggungan Keluarga (Jiwa) & Jumlah ( Jiwa ) & Persentase (\%) \\
\hline 1 & $1-3$ & 10 & 26.32 \\
2 & $4-6$ & 23 & 60.53 \\
3 & $>6$ & 5 & 13.16 \\
Jumlah & & 38 & 100 \\
\hline Rata-Rata & 5 & \\
\hline
\end{tabular}

Sumber Data: Data Olahan, 2013 
Tabel 5 menunjukkan jumlah tanggungan keluarga petani sampel, yaitu sebanyak $60,53 \%$ petani sampel mempunyai jumlah tanggungan keluarga 4-6 jiwa, sedangkan $26,32 \%$ petani sampel mempunyai tanggungan keluarga 1-3 jiwa dan 13,16\% petani sampel dengan tanggungan keluarganya $>6$. Berdasarkan data tersebut dapat dikatakan bahwa pada umumnya para petani memiliki jumlah tanggungan keluarga antara 4 - 6 jiwa, artinya dengan jumlah pendapatan petani yang berkisar Rp.6.050.480 petani telah sanggup memenuhi kebutuhan hidup keluarganya.

\section{Distribusi Pendapatan}

Pertumbuhan perekonomian yang tinggi belum tentu mencerminkan pendapatan perkapita yang diterima masyarakat tinggi dan distribusi pendapatan yang adil dan merata diantara masyarakat. Distribusi pendapatan merupakan salah satu indikator yang menunjukkan tingkat kemeratan (ketimpangan) dari suatu pendapatan yang di terima oleh masyarakat. Distribusi pendapatan mencerminkan merata atau timpangnya pembagian hasil dikalangan masyarakat. Distribusi pendapatan yang merata di kalangan masyarakat pada suatu daerah, merupakan salah satu sasaran daerah tersebut dalam melaksanakan pembangunan (Todaro, 2000).

Pertumbuhan ekonomi yang tinggi akan menjadi kurang berarti jika terdapat ketimpangan pendapatan yang cukup tinggi, karena jika pertumbuhan ekonomi yang tinggi disertai dengan distribusi pendapatan yang tidak merata (ketimpangan yang tinggi), mencerminkan sebagian besar pendapatan di nikmati oleh sebagian kecil penduduk (golongan berpendapatan tinggi), berarti sebagian besar penduduk (golongan berpendapatan rendah) menikmati sebagian kecil pendapatan daerah. Jika kondisi ini di alami oleh suatu daerah, menandakan tingginya tingkat kemiskinan didaerah tersebut.

Tabel 6. Tingkat pendapatan Keluarga Petani Karet Per Bulan Pada Tahun 2013

\begin{tabular}{clcc}
\hline No. & \multicolumn{1}{c}{ Tingkat Pendapatan (Rp) } & Jumlah (jiwa) & Persentase (\%) \\
\hline 1 & $2.000 .000-6.000 .000$ & 22 & 57,89 \\
2 & $6.000 .001-10.000 .000$ & 11 & 28,95 \\
3 & $\geq 10.000 .001$ & 5 & 13,16 \\
\hline
\end{tabular}

Sumber: Data Primer, olah data 2013.

Tabel 6. menunjukkan bahwa petani sampel terbanyak berada pada kelompok pendapatan Rp. 2.000 .000 - Rp. 6.000 .000 yaitu sebanyak $57,89 \%$. Artinya pendapatan dikelompok ini masih terbilang rendah yaitu terdapat sembilan petani dari 22 petani dikelompok ini yang hidup pas - pasan dengan pendapatan Rp.2.000.000 Rp.3.000.000 untuk memenuhi kebutuhan hidup dalam waktu sebulan. Biasanya petani ini hanya memiliki luas lahan $1 \mathrm{Ha}$ dan memiliki pekerjaan sampingan dengan pendapatan rendah. Sedangkan yang pendapatan Rp. 4.000.000 - Rp. 6.000.000 sudah dikatakan mencukupi tanggungan hidup anggota keluarganya.

Kelompok pendapatan Rp. 6.000.001Rp. 10.000.000 memiliki jumlah persentase yaitu $28,95 \%$. Artinya dengan pendapatan diatas Rp.6.000.000 petani sudah dapat memenuhi kebutuhan pokok serta kebutuhan tersier mereka. Luas Lahan yang dimiliki petani dalam kelompok ini berkisar $\geq 2 \mathrm{Ha}$ dengan pekerjaan sampingan yang tergolong besar. Sedangkan kelompok pendapatan $\geq$ Rp. 10.000.000 memiliki jumlah persentase yaitu $13,16 \%$. Kelompok ini merupakan petani sampel yang makmur dan memiliki 
luas lahan lebih dari $3 \mathrm{Ha}$ dan pekerjaan sampingan yang pendapatan besar.

Pendapatan rumah tangga sampel petani karet dapat dikatakan cukup tinggi karena hanya sebagian kecil petani dengan pendapatan pas-pasan, hal tersebut dikarenakan selain memiliki kebun karet, sebagian petani juga memiliki kerja sampingan seperti petani sawit, petani padi, peternak dan juga sebagai pedagang maupun bidang jasa.

Distribusi pendapatan digunakan untuk melihat ketimpangan pendapatan antara rumah tangga di Desa Sei. Tonang. Untuk mengetahui distribusi pendapatan dilakukan dengan mengurutkan jumlah total pendapatan rumah tangga per bulan, mulai dari total pendapatan yang terendah sampai pendapatan yang tertinggi. Kemudian membagi kedalam tiga kelompok yang masing-masing dibagi $40 \%$ terendah, $40 \%$ sedang, dan $20 \%$ tertinggi. Distribusi yang diterima oleh petani dapat dilihat pada Tabel 7.

Tabel 7. Distribusi Pendapatan yang Diterima Keluarga Petani Karet per Bulan Tahun 2013 di Desa Sei. Tonang

\begin{tabular}{cccccc}
\hline No. & $\begin{array}{c}\text { Kelompok } \\
\text { Petani (fi) }\end{array}$ & $\begin{array}{c}\text { Total Pendapatan } \\
(\text { Rp) }\end{array}$ & $\begin{array}{c}\text { Jumlah } \\
\text { Responden (jiwa) }\end{array}$ & $\begin{array}{c}\text { (\%) } \\
\text { Pendapatan } \\
\text { Rata-Rata }\end{array}$ \\
\hline 1. & $40 \%$ terendah & 52.318 .709 & 15 & 22,76 & $3.487 .913,93$ \\
2. & $40 \%$ menengah & 90.437 .018 & 15 & 39,33 & $6.029 .134,56$ \\
3. & 20\% tertinggi & 87.162 .516 & 8 & 37,91 & $10.895 .314,48$ \\
\hline & Jumlah & $\mathbf{2 2 9 . 9 1 8 . 2 4 3 , 2 5}$ & $\mathbf{3 8}$ & $\mathbf{1 0 0 . 0 0}$ \\
\hline
\end{tabular}

Sumber: Data olahan, 2013

Tabel. 7 dalam lampiran delapan menunjukkan bahwa sebanyak 15 responden termasuk dalam golongan $40 \%$ pendapatan terendah dengan total pendapatan $\mathrm{Rp}$. $22,76 \%$, 15 responden termasuk dalam golongan $40 \%$ pendapatan menengah dengan total pendapatan Rp. 39,33\%, dan 8 responden termasuk dalam golongan $20 \%$ pendapatan tertinggi dengan total pendapatan $37,91 \%$. Artinya pendapatan petani sampel di Desa Sei. Tonang berada pada golongan ratarata pendapatan menengah yaitu antara Rp.3.000.000 sampai dengan Rp.10.000.000.

Indeks Gini Ratio merupakan pendekatan yang dapat menunjukkan ketimpangan atau ketidak merataan pendapatan antara rumah tangga responden. Pada analisa ini yang dipakai adalah kriteria Indeks Gini menurut Todaro (1990) yang menetapkan kriteria:

1. Bila angka Gini Ratio berada pada nilai < 0,4 berarti distribusi pendapatan berada pada ketimpangan rendah.

2. Bila angka Gini Ratio berada pada nilai $0,4-0,5$ berarti distribusi pendapatan berada pada ketimpangan sedang.

3. Bila angka Gini Ratio berada pada nilai > 0,5 berarti tingkat ketimpangan distribusi yang tinggi.

Tabel 8. Indeks Gini Rasio Pendapatan Utama (Usahatani Karet) Petani Sampel (Rp/Bulan).

\begin{tabular}{ccccccc}
\hline No. & $\begin{array}{c}\text { Kelompok } \\
\text { Petani (fi) }\end{array}$ & $\begin{array}{c}\text { Pendapatan } \\
(\mathbf{R p})\end{array}$ & $\begin{array}{c}\text { Pendapatan } \\
(\mathbf{\%})\end{array}$ & $\begin{array}{c}\text { Kumulatif } \\
(\boldsymbol{\%})\end{array}$ & $\begin{array}{c}\text { Yi + Yi- } \\
\mathbf{1}\end{array}$ & $\begin{array}{c}\text { fi(Yi+Yi- } \\
\mathbf{1})\end{array}$ \\
\hline 1. & 40\% terendah & 34.742 .730 & 0,18 & 0,18 & 0,18 & 0.07 \\
2. & $40 \%$ menengah & 77.850 .890 & 0,40 & 0,58 & 0,76 & 0.30 \\
3. & 20\% tertinggi & 80.641 .290 & 0,42 & 1,00 & 1,76 & 0.35 \\
\hline
\end{tabular}




\begin{tabular}{|c|c|c|c|c|c|c|}
\hline No. & $\begin{array}{l}\text { Kelompok } \\
\text { Petani (fi) }\end{array}$ & $\begin{array}{c}\text { Pendapatan } \\
\text { (Rp) }\end{array}$ & $\begin{array}{c}\text { Pendapatan } \\
(\%)\end{array}$ & $\begin{array}{c}\text { Kumulatif } \\
(\%)\end{array}$ & $\begin{array}{c}\mathbf{Y i}+\mathbf{Y i}- \\
1\end{array}$ & $\begin{array}{c}\mathbf{f i}(\mathrm{Yi}+\mathrm{Yi}- \\
1)\end{array}$ \\
\hline Indel & $\begin{array}{l}\text { Jumlah } \\
\text { Gini Rasio }\end{array}$ & 193.234 .909 & 1.00 & 1,76 & 2,70 & $\begin{array}{l}0,73 \\
0,27\end{array}$ \\
\hline
\end{tabular}

Sumber Data: Data Olahan, 2013

Tabel 8 menunjukkan angka Indeks Gini Rasio petani berdasarkan pendapatan dari usahatani karet. Dapat dilihat tingkat ketimpangan yang terjadi adalah sebesar 0,27 Artinya distribusi pendapatan berada dalam ketimpangan rendah jika pendapatan rumah tangga petani karet hanya bergantung sepenuhnya pada usahatani karet. Petani yang memiliki tanaman karet yang produktif dalam jumlah yang luas akan memiliki pendapatan relatif lebih tinggi dibandingkan dengan petani yang memiliki luas lahan karet sedikit, semakin timpang pemilikan karet yang produktif maka akan semakin tinggi ketimpangan dalam distribusi pendapatannya.

Tabel 9. Indeks Gini Rasio Pendapatan Utama dan Sampingan Petani Sampel (Rp/Bulan).

\begin{tabular}{|c|c|c|c|c|c|c|}
\hline No & $\begin{array}{l}\text { Kelompok } \\
\text { Petani (fi) }\end{array}$ & $\begin{array}{c}\text { Pendapatan } \\
\text { (Rp) }\end{array}$ & Pendapatan (\%) & Kumulatif (\%) & $\begin{array}{c}\mathbf{Y} \mathbf{i}+\mathbf{Y i}- \\
1\end{array}$ & $\begin{array}{c}\mathbf{f i}(\mathbf{Y i}+\mathbf{Y i}- \\
\mathbf{1})\end{array}$ \\
\hline 1. & $40 \%$ terendah & 52.318 .709 & 0,23 & 0,23 & 0,23 & 0,09 \\
\hline 2. & $40 \%$ menengah & 90.437 .018 & 0,39 & 0,62 & 0,85 & 0,34 \\
\hline 3. & $20 \%$ tertinggi & 87.162 .516 & 0,38 & 1,00 & 1,85 & 0,37 \\
\hline Inde & $\begin{array}{l}\text { Jumlah } \\
\text { Gini Rasio }\end{array}$ & $229,918,243$ & 1,00 & 1,85 & 2,92 & $\begin{array}{l}0,80 \\
0,20\end{array}$ \\
\hline
\end{tabular}

Sumber: Data olahan 2013

Besarnya Indeks Gini Ratio untuk petani karet berdasarkan pendapatan utama dan sampingan di Desa Sei. Tonang sebesar 0,20 yang artinya bahwa distribusi pendapatan rumah tangga petani karet tingkat ketimpangannya rendah. Nilai ini berbeda jika dibandingkan dengan nilai Indeks Gini Rasio pendapatan dari usahatani karet berkisar 0,27 . Perbedaan yang didapat tidak terlalu nyata, namun rentangan nilai ini menunjukkan pendapatan rumah tangga pada wilayah yang diamati ada sumber pendapatan lain baik dari sektor pertanian maupun nonpertanian yang membawa perbaikan dalam struktur pendapatan rumah tangga dan mengurangi ketimpangan pendapatan yang terjadi pada petani karet.

Penelitian ini juga didukung hasil penelitian Putra, (2007), dengan distribusi pendapatan berada pada ketimpang sedang dengan Gini Rasio 0,476. Ketimpangan ini disebabkan perbedaaan dalam tingkat harga karet, luas lahan karet yang dimiliki serta adanya variasi pekerjaan sampingan rumah tangga petani karet. Sedangkan menurut Endang (2009), distribusi pendapatan rumah tangga di Desa Pauh Angit berada pada ketimpangan sedang dan Indeks Gini Rasio sebesar 0,32. Bedasarkan beberapa hasil penelitian di atas, bahwa kondisi distribusi pendapatan petani berada pada ketimpangan rendah hingga ketimpangan sedang.

Kurva Lorenz dapat memperlihatkan hubungan kuantitatif aktual antara persentase penerimaan pendapatan dan persentase pendapatan total yang benar-benar mereka terima. Semakin jauh jarak Kurva Lorenz dari garis diagonal (yang merupakan garis pemerataan sempurna), maka semakin timpang atau tidak merata distribusi pendapatannya. Sebaliknya, jika kurva 
semakin dekat dari garis diagonal maka distribusi pendapatan semakin merata.

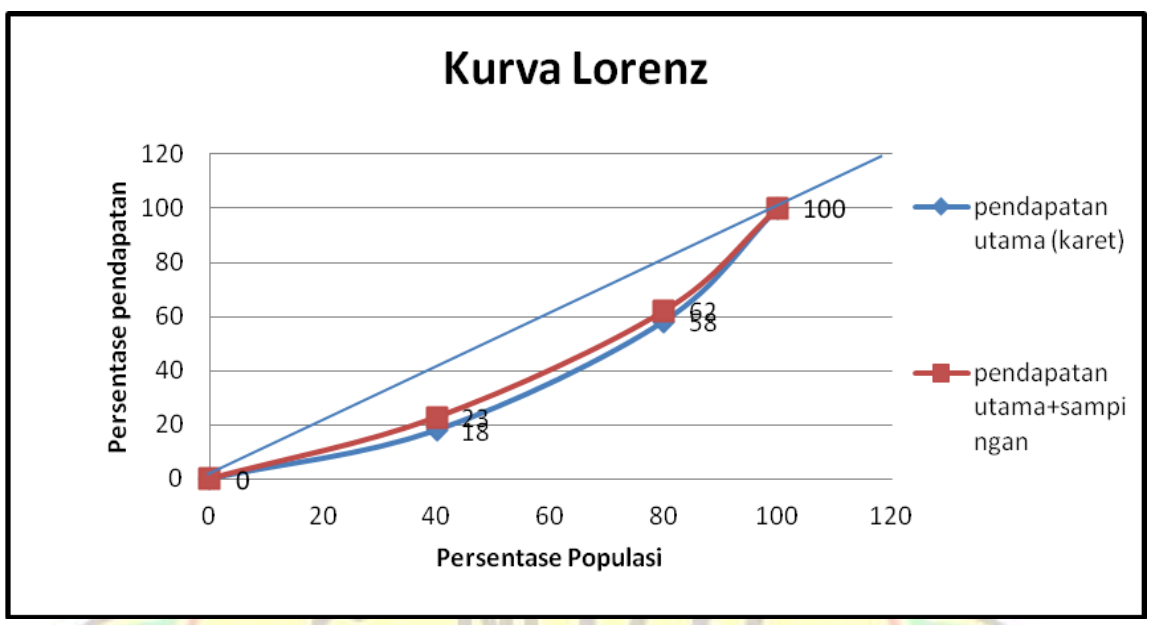

Gambar 1. Kurva Lorenz Distribusi Pendapatan Petani Karet di Desa Sei. Tonang

Berdasarkan gambar 1. Kurva Lorenz menunjukkan sebaran distribusi pendapatan penduduk disetiap lapisan rumah tangga petani karet merata, artinya tingkat kesenjangan distribusi pendapatan petani karet rendah/, hal ini terlihat dari kemiringan kurva tidak jauh dari garis 45 derajat yang merupakan garis tolak ukur distribusi pendapatan yang merata. Kurva Lorenz diatas juga menjelaskan ketika petani sampel hanya bekerja sebagai petani karet ketimpangan pendapatan yang terjadi sebesar 0,27 yaitu dalam keadaan ketimpangan pendapatan rendah. Namun ketika petani melakukan kegiatan usaha diluar usahatani karet, ketimpangan pendapatan antar golongan petani dapat berkurang hingga sebesar 0,20. Meskipun keduanya berada dalam keadaan ketimpangan rendah, Namun dari penambahan kegiatan diluar usahatani sebagai pekerjaan sampingan dapat membawa perbaikan dalam struktur pertanian. Dapat dilihat pergeseran kurva dari pendapatan usahatani karet ke kurva pendapatan petani dari pertanian dan non pertanian sebesar 0,07 yaitu dari golongan $40 \%$ terendah menerima $18 \%$ dari total pendapatan, $40 \%$ menengah menerima pendapatan $40 \%$ dari total pendapatan, dan
$20 \%$ tertinggi menerima $42 \%$ dari total pendapatan bergeser ketitik golongan $40 \%$ terendah menerima $23 \%$ dari total pendapatan, $40 \%$ menengah menerima pendapatan $39 \%$ dari total pendapatan, dan $20 \%$ tertinggi menerima $38 \%$ dari total pendapatan.

\section{KESIMPULAN DAN SARAN Kesimpulan}

Hasil penelitian serta analisis yang diperoleh terhadap rumah tangga petani karet di Desa Sei. Tonang Kecamatan Kampar Utara dapat diperoleh kesimpulan:

1. Pendapatan rumah tangga petani karet di Desa Sei. Tonang berkisar antara Rp. 2.095.913 - Rp. 15.429.336. Dengan ratarata pendapatan Rp.6.042.585. yang terdiri dari pendapatan sektor pertanian 97,26\% dan di luar sektor pertanian 2,74.

2. Distribusi pendapatan rumah tangga petani karet sudah cukup merata dengan Angka Indeks Gini Rasio sebesar 0,20 dan tingkat ketimpangan pendapatan rendah serta Kurva Lorenz mendekati garis kemerataan sempurna.

\section{Saran}

Petani agar dapat mempertahankan dan meningkatkan distribusi pendapatan yang 
diperoleh saat ini dengan melihat kepada peluang-peluangan yang ada sebagai sumber pendapatan sampingan.

\section{DAFTAR PUSTAKA}

Badan Pusat Statistik Propinsi Riau. 2010. Riau Dalam Angka 2011. BPS Propinsi Riau. Pekanbaru.

Badan Pusat Statistik Kampar. 2011. Kampar Dalam Angka 2011. BPS Kampar. Kampar.

Dinas Perkebunan Kabupaten Kampar. 2012. Perkebunan Kampar Dalam Angka. Bangkinang.

http://kamaluddin86.blogspot.com/2010/05/p emasaran karet.html. diakses pada tanggal 12-10-2012

http://www.bappenas.go.id/get-fileserver/node/522/. diakses pada tanggal 12-10-2012

http://www.deptan.go.id/infoeksekutif/bun/B UN-asem2012/Prodtv-Karet.pdf di akses 23 Novemver 2012

Irawan Rudi dan Sadikin. 2004. Dampak Pembangunan Perkebunan Karet rakyat Terhadap Kehidupan Petani Di Riau. Pusat Penelitian dan Pengembangan Sosial Ekonomi Pertanian. Bogor.

Kuncoro. Mudrajad. 2000. Ekonomi Pembangunan. Erlangga. Jakarta

Putra.P. 2007. Distribusi Pendapatan dan
Tingkat Kemiskinan Petani Karet di Desa Sei Geringging Kecamatan Kampar kiri Kabupaten Kampar, Skripsi Fakultas Pertanian, Universitas Riau. Pekanbaru. (tidak di publikasikan).

Putra L.D. 2011. Analisis Pengaruh Ketimpangan Distribusi Pendapatan terhadap Jumlah Penduduk Miskin di Propinsi Jawa Tengah Periode 20002007, Skripsi Fakultas Ekonomi, Universitas Diponegoro, Semarang. http://pustaka undip.ac.id/ di akses pada 12 september 2012 jam 22.09

Rachman, H.P.S., Supriyati dan Benny Rachman. 2002. Struktur dan Distribusi Pendapatan Rumahtangga Petani Lahan Sawah. Laoran Hasil Penelitian Kerjasama Puslitbang Sosial Ekonomi Pertanian dengan Bappenas/USAID/DAI.

Tadoro, M, 2003. Pembangunan Ekonomi di dunia Ketiga. Erlangga. Jakarta.

Widodo, S. T. 1990. Indikator Ekonomi Dasar Perhitungan Perekonomian. Kanisius. Yogyakarta.

Wulan Sri, P 2011. Distribusi Pendapatan Petani Kelapa Sawit Pola Plasma di Kecamatan Pangkalan Kuras Kabupaten Pelalawan Provinsi Riau. Universitas Riau. (tidak di publikasikan). 